\title{
Determinant of Capital Structure From Shariah-Compliant in The Industrial Products and Services
}

\author{
Ezza Nazzira Roslan, Halimatun Saadiah Khaidzir, Najwa Azman, Farah \\ Amilia Mohd Jizad, Amir Imran Zainoddin
}

To Link this Article: http://dx.doi.org/10.6007/IJARBSS/v12-i1/12194

DOI:10.6007/IJARBSS/v12-i1/12194

Received: 19 November 2021, Revised: 14 December 2021, Accepted: 06 January 2022

Published Online: 23 January 2022

In-Text Citation: (Roslan et al., 2022)

To Cite this Article: Roslan, E. N., Khaidzir, H. S., Azman, N., Jizad, F. A. M., \& Zainoddin, A. I. (2022). Determinant of Capital Structure From Shariah-Compliant in The Industrial Products and Services. International Journal of Academic Research in Business and Social Sciences, 12(1), 2548-2558.

\section{Copyright: (C) 2022 The Author(s)}

Published by Human Resource Management Academic Research Society (www.hrmars.com)

This article is published under the Creative Commons Attribution (CC BY 4.0) license. Anyone may reproduce, distribute, translate and create derivative works of this article (for both commercial and non0-commercial purposes), subject to full attribution to the original publication and authors. The full terms of this license may be seen

at: http://creativecommons.org/licences/by/4.0/legalcode

Vol. 12, No. 1, 2022, Pg. $2548-2558$

Full Terms \& Conditions of access and use can be found at http://hrmars.com/index.php/pages/detail/publication-ethics 


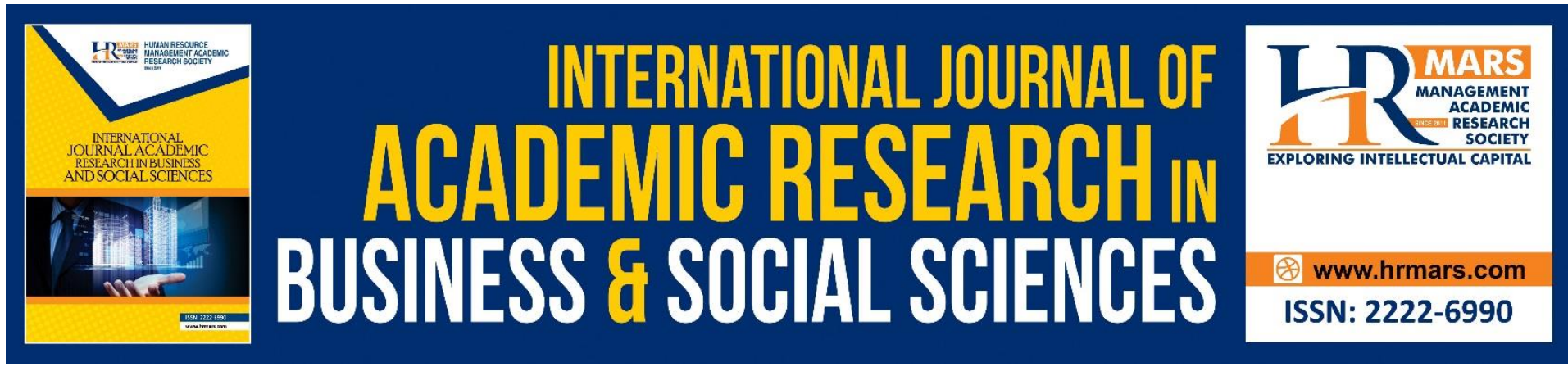

\title{
Determinant of Capital Structure From Shariah- Compliant in The Industrial Products and Services
}

\author{
Ezza Nazzira Roslan, Halimatun Saadiah Khaidzir, Najwa \\ Azman, Farah Amilia Mohd Jizad, Amir Imran Zainoddin
}

Faculty of Business and Management, Universiti Teknologi MARA Cawangan Johor, Kampus

Segamat, 8500 Segamat, Johor, Malaysia

Corresponding Author Email: amirimran@uitm.edu.my

\begin{abstract}
The purpose of this preliminary comparative study was to analyze the most reliable debt determinants identified in the literature on the Shariah-compliant in Malaysia. Depending on the measure of leverage, the influence of different independent variables on the capital structure of a Shariah firm. Shariah-compliant stocks have been heavily invested by individual investors and Muslim institutions. Firms need to deal with their capital structure to guarantee that their operation keeps on being beneficial and further development for investors and shareholders. The static panel data technique was used in this study on a sample consisting of shariah in Malaysia's firms from 2010 until 2020 and analyzed by using the E-views software. The result indicated that there is a positive correlation between firm size and profitability of shariah compliant companies listed in the Bursa Malaysia. On the other hand, there is a negative correlation between business risk.
\end{abstract}

Keywords: Capital Structure, Shariah Compliant, Eviews Software, Leverage, Profitability

\section{Introduction}

Capital structure is the combination of obligation and value capital of an organization. The organization's capital structure is vital since it is identified with the capacity of the organization to satisfy the requirements of its partners. Hypotheses of capital structure look to give a structure to seeing how financing choices are made. The fitting capital structure for an organization change relying upon their overall strategy, market environment and their short-term (3-5-year) vital strategy. This study consists of 11 years and 5 companies in the Industrial Product and Services sector.

The goal of this examination was to explore the most solid capital structure determinants of firms delegated in SC (shariah compliant). The capital structure of firms shifts with its size, type, and some different qualities, for example, the age of the company, company size, asset structure, profitability, company growth, company risk, and liquidity (AlNajjar et al., 2008). It appears that all sectors of listed companies in Bursa Malaysia are adhering to shariah-based principles except the Special Purpose Acquisition Companies (SPAC), hotels, and closed-end fund sectors. 
Generally, adhering to Shariah principles or staying Shariah-compliant means conceding strictly to the permissible (halal) and abstaining from the forbidden (haram) activities as commanded by the Islamic faith. In practice, Shariah principles infer the divine rules of forbidding interest (riba), ambiguities (gharar), gambling (maysir) and impure commodities such as intoxicants and pork (Emerald, 2017). Shariah-compliant securities are securities of a public-listed organization that have been named Shariah allowable for investment, in light of the organization's consistency with Shariah standards as far as its essential business and investment exercises just as monetary position (Jalil et al., 2019).

\section{Purpose of the Study}

Capital design incorporates money is the way how its resources make a blend of obligation, value, or cross breed protections. It additionally shows us the makeup of a company's capitalization. However, despite many academic studies on this, it shows that there is still a lack of evidence on the relationship of capital structure from shariah compliance firms. According to Yildirim et al (2018) there is limited academic research since the Shariah firm is new in the business.

Although some light has been shed on the dynamic forces that shape the typical firm debt- to-equity mix, the case of Shariah-compliant firm's capital structure behavior remains even more of a mystery. Hence, it is not possible the shariah compliance firms cannot handle the capital structure. Ogebe et al (2013) referenced that organizations will ordinarily deal with issues while organizing their capital and arranging for their wellspring of financing, regardless of whether to raise obligation or value capital to decide its suggestion towards the company's exhibition, as it is vital for the company's worth and its endurance.

In spite of the fact that there are numerous relatable studies on this issue, the quantity of studies is restricted and centered around the factor of risk in their studies. Naturally, Akinsomi et al (2019) upgraded the degree by leading a near study from property firms working under the Shariah rule against the customary property firms in Malaysia. Consequently, further study is important to recognize what sort of variables influence the capital structure of shariah organizations in Malaysia. Moreover, much existing literature focuses on the impact of capital structure to performance, considering the determinant of capital structure in Shariah compliant companies. Henceforth, this study additionally endeavors to fill in a study led by Thabet et al (2014) whereby the study incorporated the impact of capital structure from shariah firms in Malaysia.

The research is essential because it contributes to a better comprehension of the variables that impact capital structure in Malaysian companies that are shariah-compliant. The study further demonstrates how the capital structure affects the firm's valuation. In addition, the study looks at the effect of capital structure on a company's profitability. Furthermore, the research examines how capital structure represents an organization's strategies by assessing business risk on shariah-compliant firms. Finally, the study investigates the significant relationship between leverage the firm size, profitability, and business risk.

\section{Literature Review Concept of Capital Structure}

There are two or three undertakings to portray Capital Structure, the entirety of the definitions clarifies such protections and the proportionate synopses that make 
capitalization. It is the blend of various wellsprings of significant length sources. One of these definitions can imparts the assessment of capital structure endeavors to clarify the blend of protections and financing sources utilized by relationships to back genuine undertakings. As demonstrated by Aljamaan, (2018), the capital structure of an affiliation recommends the piece or enhancing specialists of its capitalization and it joins all drawn out long-term capital resources, loans, reserve, share and bond.

Capital structure is basically worried about how the firm chooses to segregate its livelihoods into two expansive bits, a fixed part that is held to meet the duties toward responsibility capital and a holding up piece that has a spot with regarded monetary patrons, (Chandra, 2015). In this manner the capital structure suggests the amalgamation of assets raised from different sources broadly assigned responsibility and worth. It might be portrayed as the level of responsibility and worth in obviously the capital that will remain to put resources into a business over a colossal stretch.

Capital structure is the suffering financing of the affiliation tended to basically by long term obligation and regard and picking the reasonable capital structure is the gigantic option of the cash related association since it is unflinchingly recognized with the worth of the firm. Gitman et al (2012) depicted capital design as the blend of significant length, responsibility and worth kept up by the firm.

\section{Leverage}

The concept of leverage is well-documented in corporate finance literature, Kapil (2011), where the word "leverage" is used to describe the use of such fixed costs, which function as a "lever" to influence a company's efficiency, such as substantially improved profitability. The "lever" for a firm is a fixed operating expense and a fixed borrowing cost. Leverage is divided into three categories which are the business's total, operational, and financial leverage. Firms can use leverage to describe a company's economic structure because it captures how dependent a company is on lending as a source of funding. Abor (2005) discovered that short-term and overall debt had a favorable association with profitability, while long-term debt had a negative relationship. Also, short-term obligations are less expensive, in which increasing short-term debt with a relatively low-interest rate will lead to an increase in profitability level.

There are two sorts of drivers of debt cost: firm-specific and environment-related. Recent research has looked at how debt cost affects optimum financing options Jules et al., (2010) the market for corporate control Qiu et al (2009) institutional investors and corporate governance (Elyasiani et al., 2010).

Apart from that, there is a tendency for large companies to use debt capital more than small and medium-sized enterprises. As a result, the size of firms influences their leverage, where large companies are less vulnerable to bankruptcy and hence less likely of bankruptcy cost to be high. According to Ezeoha et al (2010), more prominent and well-known companies have better access to the capital and stock markets than their smaller counterparts. As a result, the chance of a larger company defaulting is significantly lower than that of a smaller company. Larger companies also have a better record in the debt industry, and their credit ratings are usually higher.

\section{Firm Size}

Firm size is one of those determinants that gives predictable outcomes in its relationship to use. According to Pandey (2004), defines company size as the total value of an 
organization's assets. The effect of the size impact on influence relies upon which capital structure theory to look at. Bigger firms by deals or work have higher influence. A lower riskfree rate benefits greater firms more as they can switch more and existing firms purchase a greater amount of the new assortments showing up into the economy. This prompts lower startup rates and a more prominent grouping of deals (Sanil et al., 2018). The positive connection among influence and firm size is clarified in the accompanying manner. The first, organization proprietors are accepted to be more restless than banks, and accordingly will in general acquire against their organizations' potential income.

Second, organizations keep up changing quantities of product types, every one of which is believed to be dependent upon autonomous elimination stun. This arrangement infers that bigger firms have a lower coefficient of variety of deals and business, which permits them to have higher influence. The lower scattering of work among bigger firms that the model produces is reliable with the information revealed in (Davis et.al., 2009). Accordingly, bigger organizations will actually want to give value at lower costs which will mean a lower influence proportion, and bigger organizations are accepted to have had a chance to hold income (Frank et al., 2009).

\section{Profitability}

Profitability can be defined as an ability to make income or profit from all kinds of the business such as activities of an organization, company, or an enterprise Penman, (2007). It is different from a profit since profit is determined by amounts of sales from the company expenses while profitability is when a company has the ability to produce a return on an investment based on its assets or resources. According to Ali et al., (2018), profitability is the key role for any firm to remain or run the business for a long time. Although profitability is the objective goal of all businesses, there still are factors that affect profitability for the firms. Failing projects can quickly decrease the performance of a company, which directly leads to loss and more leverage.

To determine whether a project is worth or not, firms can calculate or explore profitability index to reduce from the failures of the project. According to research from Van and Wachowicz (2008) the key point for profitability is from profitability ratio because the ratios are able to measure the efficiency of performance companies. The most important measurement to evaluate profitability of a company is return on assets (ROA). Description of return on asset when the ratio of net income to total assets is high, the performance of the company will be better (Goddard, 2005).

Besides from using return on asset (ROA), there are measurement that can influence of using structure of finance such as earnings before interest and taxes (EBIT) Akintoye, (2008), or expressing it through economic value added (EVA), return on equity (ROE), operating profit margin (OPM) and EPS. It is important to use many tools or variants to gain more information about firms when determining the profitability index of a company.

\section{Business Risk}

The use of leverage has an impact on a firm's risk. Business risk refers to a company's or organization's exposure to factors that could reduce profitability or cause it to fail. According to Ndegwa, (2001), defines business risk as the variation of a firm's operating income and expected dividends as a result of its operating conditions. Everything that can be threatened in a company for achieving their financial goals are considered a business risk. The probability of the firm defaulting on its debt payment will increase as the firm's earnings 
volatility rises. If creditors wish to extend additional loans to risk firms, they will face higher financial charges. The level of trust in creditors will be lowered as a result of this. According to the Trade-Off Theory, businesses should lower their debt volume and reduce their chance of bankruptcy.

According to Basri (2021), large firms experience a lower chance of bankruptcy, which leads to the usage of higher debt financing resulting in a more efficient access to capital than small companies. According to Frank et al (2009) earnings volatility may limit the probability of taking full advantage of the benefits of tax shelters, resulting in lower debt levels. Because of the higher financial risk, companies with high operating risk use less debt in their debt equity mix. As a result, businesses operating in high-risk environments should minimize their debt utilization in order to reduce business risk, which will lower their bankruptcy risk. This demonstrates that the use of debt has an inverse relationship with company risk and bankruptcy risk (Andersen, 2010). For instance, academic studies such as Sorokina (2014) discovered almost a negative relationship between business risk and leverage, as estimated by the Trade-Off Theory.

\section{Methodology}

Research methodology is the specific strategies or method used to recognize, select, measure, and investigate data about a point. In an exploration paper, the system segment permits the peruser to fundamentally evaluate an examination's overall authenticity and relentless quality (Libguides, 2021). The fundamental means to be accomplished in this section is to talk about and further elaborate the technique for examinations utilized in distinguishing the research problem of "Determinant of capital structure from shariahcompliant firms".

The research study will be completed utilizing optional data and gathered from different sources like each organization's annual report, Data Stream, and Bursa Malaysia. Every information was for a measure of eleven (11) a long time from 2010 to 2020. Clarification in this specific section will incorporate the exploration plan and its strategies, factors and estimation, information assortment strategy, and information examination required all through this examination.

\section{Types of Investigation}

The kind of research directed in this investigation is a causal report just as a relationship study. The distinction between these two investigations is correlational examination endeavors to decide how related at least two factors are while causal-near research endeavors to distinguish a reason impact connection between at least two gatherings. Hypothesis testing was performed to recognize change and to anticipate the degree of significance between the dependent and independent variables.

\section{Sampling}

The population in this research focuses on the industrial product and services sector of shariah firms that are currently operating in Malaysia. According to the latest data in Securities Commission Malaysia in November 2020, total listed companies including shariah and non-shariah firms in the industrial product and services sector are 257 companies in Malaysia. The current population of shariah firms in Malaysia are 212. The sample is taken among the population and the sample size of this research is 5 shariah firms from the period 
starting from 2010 to 2020 . The firms were chosen based on the availability of the data for 11 years.

Techniques that have been applied for our research are Non-Probability Sampling because Probability Sampling Technique could not be applied in this exploration due to limitation towards data and list that could be obtained among the population. One of the Non-Probability Sampling that has been involved in this research is Judgement Sampling because it was applied as it includes for only choosing components to give the data required. For instance, the only sorting elements in this research are all the shariah firms.

The sample of shariah firms in the period of 2010 to 2020 are AT Systematization Berhad, Ann Joo Resources Bhd, Dufu Technology Corp. Berhad, Bintai Kinden Corporation Berhad and Boustead Holdings Berhad.

\section{Data Collection}

Data collection is the process of collecting scientific data in order to obtain new insights into a situation and to respond to the concerns that prompted the study Kothari, (2004). Since the data is quantitative, the analysis relied on secondary sources. Annual reports, databases, other publications, papers, and other secondary documents are archives of studies that use primary data to address research issues and collect evidence. The data was obtained from the selected five shariah firms that are listed on the Bursa Malaysia stock exchange. From annual reports, the data used to calculate the leverage, profit, total assets, and earnings before interest tax of the listed firms will be taken from the company's annual report on an annual basis for each year used in this study. Researchers can access all the financial information needed for this research quickly through the report on the companies' website. The data was collected between the years 2010 and 2020. Also, the study uses DataStream to locate some relevant data that can be used in the analysis. Thomson Reuters DataStream is a financial information system that offers a wide range of in-depth financial information in a workspace that is tailored to the requirements and workflow of its users.

\section{Framework}

The theoretical structure for this analysis is depicted in the figure below. Figure 1.0 shows the determinants that affect capital structure of shariah-compliant firms. The research's dependent variable is leverage. Firm size, profitability, and business risk are the independent variables. Hypotheses are linked to the relationship between the independent and dependent variables.

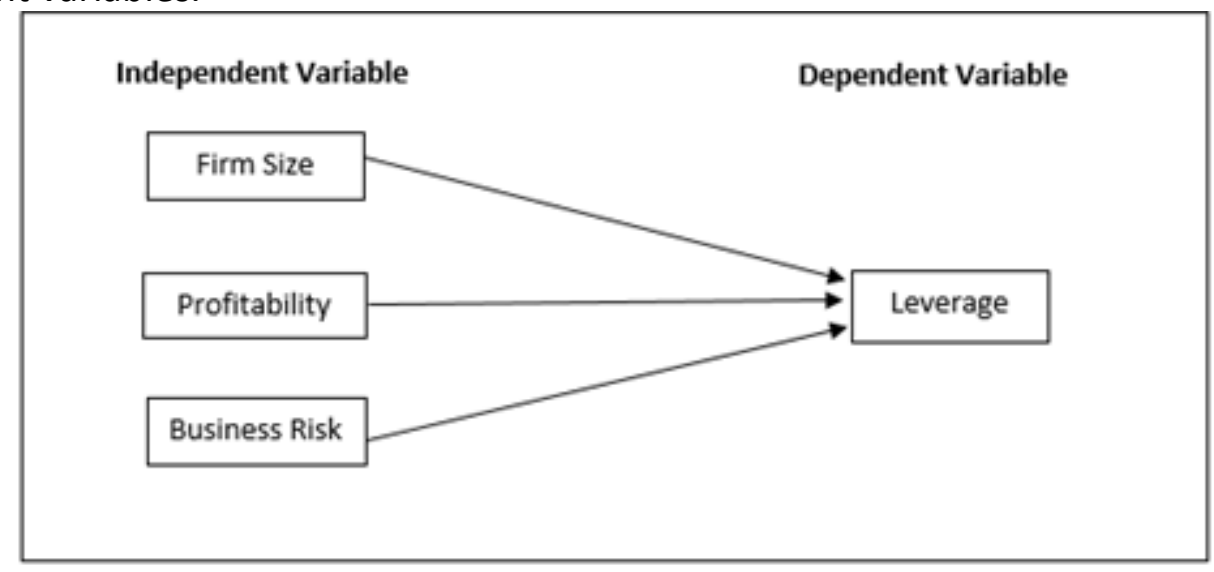

Figure 1.0: Theoretical Framework 
Result Regression Analysis

\begin{tabular}{|c|c|c|c|}
\hline $\begin{array}{c}\text { Independent } \\
\text { Variable }\end{array}$ & Coefficient & P-value & Significance (/) \\
\hline Firm Size & -0.4564 & 0.0012 & $/$ \\
\hline Profitability & -0.2481 & 0.0067 & $\mathrm{x}$ \\
\hline Business Risk & 0.0026 & 0.6962 & \\
\hline
\end{tabular}

Table 1.0: Regression Analysis

In this regression, it is used to evaluate the relationship between variables of two or more and needs to decide whether independent variables explain the dependent variable effect. In table 2.0 is the result of the regression analysis in shariah-compliant with the observation of 11 years from 2010 to 2020. By analyzing the formula of econometrics, the results can be described. The value used for the econometric equation is the value of the coefficient, so the econometric formula is in below:

$$
Y=6.5377+(-0.4564) \text { SIZE + (-0.2481) PROFITABILITY + 0.0026 RISK + e }
$$

Based on the equation, independent variables of firm size and profitability showed a negative correlation while business risk showed a positive correlation with leverage.

The firm size is the first component. The table shows that the firm size coefficient for a shariah firm is -0.4564 , which is $-45.64 \%$. It assumes that for each one percent increase in the firm size, a 45.64 percent decrease in return for the financial firm's leverage that assumes the other factors will remain the same. The probability value is 0.0012 , which is less than the 5 percent significance level. This means that the null hypothesis has to be discarded as the result can be changed in the average of the firm size that would lead to a significant impact on leverage.

Secondly, profitability is the second independent variable. It shows that the profitability coefficient value is -0.2481 , which is $-24.81 \%$. The result for each one percent increase in profitability can impact a 24.81 percent decrease in return for the leverage on shariah firms by assuming constant for other variables. The probability value is 0.0067 , which is less than the 5 percent significance level. It means that the null hypothesis needs to be rejected and the result would be changed in profitability that can lead to a significant impact on leverage.

Lastly, the final indicator for shariah firms is the business risk and it shows that the business risk coefficient value is 0.0026 which is $0.26 \%$. It shows that each percentage increase in the business risk will result in an increase of 0.26 percent in exchange for shariah firm leverage, given that the other factors will remain the same. Business risk can also lead to the smallest change in leverages. The figure of probability for these variables is 0.6962 , which is more than a 5 percent significance level. It means that the null hypothesis cannot be 
rejected and changes in business risk would result in an effect of significance against leverage on shariah firms.

\section{Conclusion}

The objective of this study is to investigate the determinant of capital in shariah firms in industrial products and services. The result is based on our regression model with three factors which are firm size, profitability and business risk as determinants of capital structure and leverage as our dependent variable. Based on the data, we can conclude that the capital structure in shariah compliance in the industrial products and services for firm size is significant with the value of 0.0012. According to (Baker \& Martin, 2011), larger organizations have a more diverse business portfolio, which means less cash flow volatility, fewer financial distress costs, and a reduced risk of bankruptcy than smaller businesses.

Next, the result for our second variable which is profitability is significant with the value of 0.0067 . According to Mousa et al (2018) the income has been more valuable since high profit has increased. This result has been supported by (Kaur et.al., 2009) and (Zhang,2010). However, for business risk is insignificant with the value of 0.6962 . According to Yildirim (2018), the findings support the Trade-Off Theory, which states that the larger a company grows, the less it is exposed to bankruptcy risk and, as a result, the more debt it tends to retain. Therefore, when reducing the leverage may enhance its ability for the shortterm obligation.

As for recommendation, it is advisable to do more research on this topic by providing more variables. This is because there is more study you can find that can be relatable to the capital structure. Hence, further study is highly recommended with additional or more variables as for example further research on tangibility and GDP growth. Based on Yildirim R, (2018) they provided more variables which are tangibility, GDP growth and growth opportunity. They have proved that the more variables added the more chances the variables to be significant. Next, it is also advisable for those who continue doing the research to apply more observations. This is because adding more observations can give you a significant result in your data. In this research we include 11 observations so it is suggested to go up for 20 or more observations. Based on (Yildirim R, 2018) they have provided over 5562 for shariah compliant and 4021 for non shariah compliant. With more observations included, the results are more significant.

\section{Reference}

Abor, J. (2005). The effect of capital structure on profitability: an empirical analysis of listed firms in Ghana. Journal of Risk Finance, 6(5), 438-445. https://doi.org/10.1108/15265940510633505

Akinsomi, O., Ong, S. E., Ibrahim, M. F., \& Newell, G. (2019). Does Being Islamic or ShariahCompliant Affect Capital Structure? Evidence from Real-estate Firms in the Gulf Cooperation Council States. SSRN Electronic Journal, 1-27. https://doi.org/10.2139/ssrn.3346456

Akintoye, I. R. (2008). Effect of capital structure on firms' performance: The Nigeria performance. European Journal of Economics, Finance and Administrative Sciences, 10, 233-243.

Al-Najjar, B., \& Taylor, P. (2008). The relationship between capital structure and ownership structure: New evidence from Jordanian panel data. Managerial Finance, 34(12), 919- 
933. https://doi.org/10.1108/03074350810915851

Alarussi, A. S., \& Alhaderi, S. M. (2018), "Factors affecting profitability in Malaysia", Journal of Economic Studies, Vol. 45 No. 3, pp. 442-458. https://doi.org/10.1108/JES-05-20170124

Aljamaan, B. E. (2018). Capital Structure: Definitions, Determinants, Theories And Link With Performance Literature Review Bader Eid Aljamaan Teaching Assistant Of Finance And Business, Almajmaah University, Saudi Arabia. European Journal Of Accounting Auditing And Finance Research, 6(2), 49-72.

Chandra, T. (2015). The Determinants of the Capital Structure: Empirical Evidence from Indonesian Stock Exchange Companies. Revista Kasmera, 43(2), 76-87.

Elyasiani, E., Jia, J. J., \& Mao, C. X. (2010). Institutional ownership stability and the cost of debt. Journal of Financial Markets, 13(4), 475-500. https://doi.org/10.1016/j.finmar.2010.05.001

Ezeoha, A. E., \& Okafor, F. O. (2010). Local corporate ownership and capital structure decisions in Nigeria: A developing country perspective. Corporate Governance, 10(3). https://doi.org/10.1108/14720701011051893

Frank, M. Z., \& Goyal, V. K. (2009). Capital structure decisions: Which factors are reliably important? Financial Management, 38(1). https://doi.org/10.1111/j.1755053X.2009.01026.x

Gitman, L. J., Zutter, C. J. (2012). Managerial Finance. In Ankara Üniversitesi SBF Dergisi (Vol. 24, Issue 3). https://doi.org/10.1501/sbfder_0000001153

Jalil, A., \& Osman, S. (2019). Development of Shariah Compliance and Governance Regulations within the Malaysian Islamic Banking Industry: An Analysis. International Islamic Economic System Conference, November, 1-12.

Kapil, Sh. (2011). Financial Management. Dorling Kindersley (India) Pvt. Ltd. 725 p.

Kothari, C. R. (2004) Research Methodology: Methods and Techniques (Vol.148). 2nd Edition, New Age International Publishers, New Delhi.

Ndegwa, S. N. (2001). Systematic risk and business risk: a case of companies listed atthe Nairobi stock exchange. (MBA thesis, University of Nairobi, Nairobi, Kenya). http://erepository.uonbi.ac.ke/handle/11295/21913.

Ogebe, P. O., Ogebe, J. O., \& Alewi, K. (2013). The Impact of Capital Structure on Firms' Performance in Nigeria (Chapters 1-5). SSRN Electronic Journal, 46173. https://doi.org/10.2139/ssrn.2232445

Pandey, I. M., \& Chotigeat, T. (2004), "Theories Of Capital Structure: Evidence From An Emerging Market", Studies In Economics And Finance, Vol. 22 No. 2, Pp. 1-19. https://doi.org/10.1108/eb028777

Qiu, J., \& Yu, F. (2009). The market for corporate control and the cost of debt. Journal of Financial Economics, 93(3), 505-524. https://doi.org/10.1016/j.jfineco.2008.10.002

Rehan, R., \& Abdul Hadi, A. R. (2019). Capital structure determinants of Shariah and NonShariah companies at Bursa Malaysia - Dynamic approach. International Journal of Innovation, Creativity and Change, 6(8), 334-345.

Sahudin, Z., Ismail, Z., Sulaiman, S., Rahman, H. A., \& Jaafar, M. N. (2019). Capital Structure Determinants of Shariah-compliant Firms. Journal of Emerging Economies and Islamic Research, 7(1), 65. https://doi.org/10.24191/jeeir.v7i1.7256

Sanil, H. S., Noraidi, A. A. A. bin, \& Ramakrishnan, S. (2018). The Impact of Different Firm Sizes on Capital Structure Determinants Among Listed Consumer Product Firms In Malaysia. Journal of Economic Info, 5(2), 1-6. https://doi.org/10.31580/jei.v5i2.104 
Stephen, H. P. (2007). Financial statement analysis and security valuation (3rd ed). ISBN-10: 007-125432-3," The International Journal of Accounting, Elsevier, vol. 42(4), pages 450453.

Thabet, O. Bin, \& Hanefah, M. M. (2014). Capital Structure in Islamic Capital Markets: Evidences From Bursa Malaysia. Proceedings of the Australian Academy of Business and Social Sciences Conference 2014, 2014(2001), 1-12. https://www.aabss.org.au/system/files/published/AABSS2014_005.pdf

Wachowicz, J., \& Van Horne, J. (2008). Fundamentals of Financial Management, 13th Edition. http://www.pearsoned.co.uk/wachowicz

Andersen, T. J., \& Schroder, P. W. (2010). Strategic Risk Management Practice: How to Deal with Major Corporate Exposures. Cambridge, United Kingdom: Cambridge University Press.

Andersen, T. J., \& Schroder, P. W. (2010). Strategic Risk Management Practice: How to Deal with Major Corporate Exposures. Cambridge, United Kingdom: Cambridge University Pres 